\title{
CONGRESSIONAL REVIEW OF PRICE CONTROL
}

\section{William C. Burt $\dagger$ and William F. Kennedy $\$$}

Price control pervades virtually the entire economy. When the Defense Production Act is up for renewal, all the forces that mold Congressional action are focused on the Congressional review of the activities of the Office of Price Stabilization. The renewal of price control legislation, therefore, presents an exceptional opportunity to study Congressional review and to appraise its effectiveness.

No one who has worked for an administrative agency can doubt the value of Congressional review. Throughout the Government generally, many an indefensible agency action has been stillborn because of the realization that all agency action faces the possibility of scrutiny by a Congressional committee. The possibility of a public hearing before a committee of Congress is not only a protection to all individuals dealing with the agency but leads to sounder standards of judgment and greater attention to facts in arriving at an agency conclusion. Without such criticism, agency action would become more arbitrary and the discipline within the agency itself would deteriorate.

Certainly one of the most salutary policies of both the OPS and the OPA has been that of publishing openly the general standards on which its actions are based. This publication has been supplemented by public expressions in statements of considerations supporting a general price regulation and by the prescription of criteria for individual pricing action. This open door policy not only has been valuable in informing individuals dealing with price control as to their rights and assuring that all individuals who meet the standards receive the same treatment without discrimination, but it has imposed a healthy discipline on all the internal activities of the agency. To some extent this policy was dictated by the requirements of the statute ${ }^{1}$

$\dagger$ B.S., 1937, LL.B., 1939, University of Illinois, Deputy Chief Counsel, Office of Price Stabilization. Member of the Illinois and District of Columbia Bars.

$\ddagger$ B.S., 1939, LL.B., 1943, Fordham University. Associate Chief Counsel, Office of Price Stabilization. Member of the New York Bar.

The views expressed in the article are personal and do not necessarily represent the views of the Office of Price Stabilization.

1. The Defense Production Act requires that regulations shall be accompanied by a statement of considerations involved in the issuance of the regulations. 64 STAT. 803 (1950), 50 U.S.C. APP. \$2102(c) (Supp. 1952). 
and by the necessities of judicial review. The policy was also promoted, however, by the knowledge that the activities of the agency would be subject to examination by Congress.

Congressional review of agency action presents basically the same questions as judicial review. Both are made necessary by the delegation of large amounts of discretionary power to administrative agencies. This delegation in turn was required by the difficulty and complexity of the problems requiring government action. Underlying both types of review is the recognition that such large powers have been delegated, that review is necessary to assure fair and responsible agency action. It is true that the scope of judicial review has its analogy in long established legal practice ${ }^{2}$ and its procedures are based on the traditional legal disciplines. Congressional review, on the other hand, has its origins in the political traditions of the legislature, whose primary function is to reconcile and compromise conflicting political interests. Its procedures are devised to cope with the problems of balancing diverse political interests. While the court's primary concern is that an agency act within the framework of delegated power, the legislature is concerned with the more basic question of how much power should be delegated. For these reasons the issues are viewed in a different frame of reference. But the fundamental problem is the same. In both cases there is the basic question of maintaining the proper relationship between the common-sense generalized knowledge of experienced nonexperts and the technical knowledge of experts which is necessary to the intelligent handling of the complex problems faced by modern government.

The modern government administrator is supported by expert staffs which have accumulated experience and judgment in dealing with particular problems. But sound government cannot give the final decision on policy to experts no matter how much they know. The experts are not elected or sensitive to the demands of the people. Moreover all government, including the courts, depends upon the sound common sense derived from general experience of persons not technically expert in the field in which they pass judgment. The basic decisions of government depend not upon expert knowledge but upon the sound judgment and insight of men of broad experience.

The fact that the control of basic governmental policy must be in nontechnical hands makes it important that, within the basic policies, sufficient discretion be vested in an agency with technical competence to do an intelligent job. The courts have recognized that

2. Judicial review of administrative action is, of course, analogous to judicial review of jury verdicts. See discussion in Davis, AdminIstratrve Law 877-8 (1951). 
they have neither the staff nor the facilities to do the job of the administrative agencies. Consequently, most courts have limited their function to the correction of actions which are clearly wrong, either because they are arbitrary or discriminatory or because they are unsupported by facts, and to cases where the procedure of the administrative agency is unfair to the participants. ${ }^{3}$ They have hoped through general guidance to impose upon administrative agencies fair procedures, standards of factual determination, and freedom from discrimination which will protect persons subject to the jurisdiction of the agency.

At least in its review of price control legislation, Congress, unlike the courts, made no effort to maintain a balance between the job of the non-expert reviewer and the expert administrator. ${ }^{4}$ It did not confine itself to resolving the general political problems raised by price control. It decided the most detailed ${ }^{5}$ and technical questions. In amendments to price control legislation, even basic ones, technical knowledge is important. Simple amendments designed for small situations often have large implications which cannot be understood with-

3. NLRB v. Columbia Enameling and Stamping Co., 306 U.S. 292 (1939); Consolidated Edison Co. v. NLRB, 305 U.S. 197 (1938). Of course, the actual extent of review and the degree of discretion allowed in a particular case vary widely among courts even if the same principle is applied. See Stason, Substantial Evidence in Administrative Law, 89 U. OF PA. L. Rev. 1026 (1941). Congress, in prescribing standards of judicial review of price control action, has been careful to preserve a wide area of discretion in the agency. 56 STAT. 31 (1942), 50 U.S.C. APP. \$ 924 (1946) ; 64 STAT. 808 (1950); 50 U.S.C. ApP. \$2108(b) (Supp. 1952); 66 Stat. 302 (1952).

4. "Technology has created problems which cannot be solved by political standards alone, by the balancing of the interests of various groups and arriving at some sort of synthesis. The social consequences of technology demand the use of experts, both as administrators and as over-all co-ordinators. . . . Does it mean that the technicians ... - will spin plans for the government, remaining impervious to political responsibility by hiding behind the stone walls of the Civil Service? . . . . the political expert has a broader grasp of the whole picture and . . . is mote alert to the necessary political adjustments which must be made. . . Congress should concentrate its attention on the broad political questions . . . it should study them and mediate on them, and so far as possible, turn over the duties which are not so time-consuming to the bureaucracy and to its own staff." Young, THIs Is CoNGREss 24-7 (1946). See also Congressional Oversight of Administrative Agencies, 5 N.Y.B.A. REC. 11 (1950).

5. In 1952, for example, Congress eliminated imaginary restrictions on kosher slaughter, 66 STAT. 296 (1952); defined the method of fixing prices for processing retailers of food, 66 STAT. 298 (1952); determined that a sale of fertilizer to a farmer was a sale at retail under the General Ceiling Price Regulation, 66 STAT. 298 (1952); exempted charges for the use of washroom and toilet facilities and bowling alleys, 66 STat. 299 (1952); limited the intervention of OPS in rate cases, 66 STAT. 299 (1952); exempted charges for state and local governments, 66 STAT. 299 (1952); and determined the method of fixing ceiling prices for hotel supply houses and wholesalers affiliated with meat slaughterers, 66 STAT. 300 (1952). Amendments of this type present the most obvious kind of legislation for lobbies. Moreover, clearly these are not the kind of issues with which Congress can effectively deal. The demands on the time of Congressmen are so great in any event that such time as they are able to devote to price control should be confined to the bigger issues. 
out a technical knowledge of the problem. Many general amendments have common-sense appeal but will make a practical hash of price control. It takes expertness to understand the implications of the amendments. ${ }^{b}$ Congress acted upon many of these either without consulting or against the advice of those most familiar with the problems.

The problem is accentuated because Congressional procedures do not provide for the systematic presentation of facts and argument necessary for the proper resolution of the more technical problems. The lack of facilities, the influence of pressure groups, the conflict between the executive and the legislature and the lack of party responsibility have in many instances prevented a careful, critical, and fair appraisal of administrative operations. This is not to say that the regulatory activities of the OPS were above criticism or that the OPS took full advantage of its opportunities in its dealings with Congress. Unquestionably the OPS made many mistakes in developing its price control program and in its Congressional relations. However, an appraisal of the activities of the OPS is not the subject of this article. We are here concerned only with an appraisal of Congressional activities in reviewing the activities of the OPS.

\section{Effectiveness of Congressional Review}

Committee Procedure.-Congressional committees do not have the time and facilities to understand fully the operations of an administrative agency despite the fact that they work long and hard. While the members of these committees absorb a general familiarity with price control problems, they have so many responsibilities and duties that they cannot spend the time necessary to attain technical competence.

Nor are the committee hearing procedures designed to produce a systematic analysis of the problems. ${ }^{7}$ The committee primarily hears testimony from citizens who believe that they have been unfairly injured by the price control agency. ${ }^{8}$ Most of this testimony is ex-

6. See discussion of the Capehart, Butler-Hope and Herlong Amendments, infra.

7. Considering the antagonism that exists between the executive and legislative branches, the Banking and Currency Committees exhibit remarkable courtesy in the examination of executive witnesses. It is true that some Congressmen enjoy the role of inquisitor. It is true that the opposition party is more animated in the attack than is the majority party in the defense. These things are to be expected. On balance, the courtesy is remarkable, particularly in view of the fact that no Congressional leader can continue to enjoy prestige among his colleagues if he says too many good things about bureaucrats.

8. While the committees are seeking information from witnesses, certainly one of the purposes of the hearings is to clear the air by letting witnesses blow off steam. 
tremely partisan and super critical. ${ }^{9}$ The administrator, on the other hand, stung by irresponsible attack, mobilizes all his resources to present expert testimony proving that everything the agency did was right. The hearing procedures thus tend to produce extreme and undisciplined attacks on price control answered by dogmatic defenses bolstered by all the facilities of the price control agency. There is no systematic presentation of facts and argument such as characterizes court procedures.

To some extent the deficiencies in the hearing procedure are overcome by staff work on the part of the professional staff attached to the committees. These staff members present to the committee summaries of many of the issues and evidence presented by the hearings. Despite the efforts and the competence of the staff, the effectiveness of their work is limited by the fact that the staff is too small to analyze completely the many issues and facts involved and that committee members are too busy to absorb even a summary staff presentation.

Procedure on the Floor.-On the floor of the House and Senate there is also little chance for analysis of details of the agency operations and for the appraisal of special amendments. Passage of important legislation free from amendment is dependent not upon traditions of party responsibility or acceptance of the work of relatively expert committees, but on the personal prestige of the chairman and the members of the committee and upon their capacity to negotiate and to deal with the members of their chamber. Such negotiation is easier in the Senate because the smaller number of members makes possible closer working relationships among the members themselves. Thus, Senator Maybank, Chairman of the Senate Banking and Currency Committee, has been able by and large to control the destinies of the price control bills reported out by his Committee on the floor of the Senate and the scope of the amendments proposed on the floor. It

9. Thus a representative of the Independent Petroleum Association of America charged that "one of the basic purposes of the Act-namely, the expansion of productive capacity of vital defense materials [crude oil]-is being ignored and even defeated through the application of the price control authority granted by the Congress." Hearings before the House Committee on Banking and Currency on H.R. 6546, 82d Cong., 2d Sess. 718 (1952).

The facts were that: (1) in 1951, under price control a record addition was made to petroleum reserves; (2) at the end of 1951 known crude oil reserves were the highest in history; (3) despite shortages of steel and drilling equipment, a record number of new wells were drilled in $1951 ;$ (4) indications are that the number of new wells drilled in 1952 will exceed the number drilled in 1951; (5) all demands for crude petroleum are now being met and we are producing at substantially less than capacity; (6) stores of crude oil above ground increased beyond expectations in 1951 and have further increased in 1952; and (7) profits in the petroleum industry even after taxes had probably never been higher. Ibid 1501. 
is not party leadership, but the personal prestige of Senator Maybank that has made this possible.

Since the House is a larger body, party discipline is at a minimum. It is virtually impossible for a committee chairman to reach agreement with all the members of the House prior to introduction of the bill on the floor. The result has been that after the House Banking and Currency Committee introduced its 1952 extension bill under an open rule, a total of 37 amendments were offered on the floor itself. Many of these amendments were superficially appealing, but actually inconsistent with the purposes of the bill itself. The House passed the bill with 22 amendments. For all practical purposes, these amendments destroyed price control. ${ }^{10}$ Such important and difficult amendments as the Herlong and Harrison amendments were floor amendments. ${ }^{11}$

Congress, of course, has a right to end price control at any time it sees fit. But the important point is that, in debate of amendments on the floor of the House, the average Congressman has no opportunity to be educated as to the nature of the amendment or its effect on price control. Debate is limited by the five minute rule, and most members of the Congress are not present when the debate is taking place. Individual Congressmen cannot vote on the basis of an intelligent appraisal of whether a particular amendment is right or wrong because the facts are not available to them.

Moreover, Congressmen on the floor of the House are peculiarly vulnerable to pressure groups. Where a Congressman can vote for a whole bill, even if it contains features opposed by particular constituents, he can tell his constituents that he had to vote for the whole bill even though the particular feature was in it. When, however, a bill is open to detailed floor amendment with a record vote, a Congressman has to stand up and be counted on a particular amendment which particular constituents want. The result in the absence of party or strong personal leadership from the chairman of the committee is a lobbyist's field day.

The Conference Committee.-The Conference Committee, sellected in the instance of price control from members of the House and Senate Banking and Currency Committees, is usually composed of the most influential members of both houses of Congress in the field of the legislation being considered. It, therefore, can be an active force

10. For example, the House passed the Talle Amendment, later deleted by the Conference, which would have limited price control to materials under allocation. 98 Cong. Rec. 8345 (June 26, 1952). This amendment would have ended virtually all controls. Only a few basic metals were under allocation. All consumer goods and all food would have been freed from control.

11. See discussion, p. 358 and pp. 351, 364 infra. 
in the development of a better law. The members are likely to be of conservative temperament because seniority plays an important role in the selection of the membership of the committee. Senior Republicans are likely to come from the most conservative districts where they are able to survive Democratic landslides. Senior Democrats are likely to belong to the more conservative Southern wing of the party. Under strong leadership, as in 1952, the Conference Committee has an opportunity to eliminate ill-considered amendments adopted during the floor debate. But the Conference also presents a chance to incorporate into the final bill amendments designed to compromise differences between the two chambers. These compromises, it is true, must be within the general framework of the bill as passed by the two Houses. Within this framework there is considerable opportunity to make radical changes in the law which not only are generally hastily prepared, but which have never been discussed or considered in the House or Senate committees or on the floor. The unfortunate third sentence of the Capehart amendment owes its birth to just such a compromise. ${ }^{12}$

\section{The Effect on Congressional Review of the Division Between the Executrve and the Legislature and the Lack of Party RESPONSIBILITY}

There are substantial differences between the influences that elect a President and those that elect legislators. This is a country with large and varied local interests. Both local and national considerations influence the election of the President and the legislators. The President, however, generally owes his election more to a national political organization and to his sensitivity to national problems. Legislators more often owe their election more to local political organizations and to their sensitivity to local problems. ${ }^{13}$

12. See discussion p. 344 infra.

13. "The structure of the American party system and its manifestation in Congress accentuate the strains on the American legislator. $\mathrm{He}$ is very much on his own. The national party does not arrange his candidacy; it has little control over the machine on which the congressman depends for his re-election; and its financial aid for the conduct of his campaign is much less than adequate. He must keep his machine going. Like an ambassador who is uneasy that his enemies at home are undoing his work and undermining his position while he is away, the legislator must always keep his eye on the machine at home-fearing that it might break out of his control during his absence in Washington.

"American constituents, at least a sector of them, are often very outspoken in their demands. The American legislator is moreover hypersensitive to the faintest whisper of a constituent's voice. Unable to depend on the national party for reelection, he must cultivate and nurture his constituency more than legislators in other democratic countries where constituents are less clamorous and parties are stronger at the center." Shils, The Legislator and His Environment, U. oF CHI. L. REv. 572 (1951). See also Hyneman, Bureaucracy in a Democracy 160 (1950). 
This situation has two results that profoundly affect the nature of our government. First, there is apt to be a split between the executive and legislative branches of the government. The President's policy is apt to be dominated by his allegiance to national groups and his conception of the national interest. Congressional policy is apt to be dominated by the influence of a cumulation of diverse local groups. Second, there is no party policy supported by both branches of the government and backed by party discipline. On many issues, including many aspects of price control, the alliance of conservative Southern Democrats and Republicans has been stronger than the majority of the Democratic Party in Congress. ${ }^{14}$ Moreover, the divergence of local interests in this large country are too great to permit agreement on a firm national policy backed by party discipline. ${ }^{15}$

It may be argued the Congressional processes of reconciling diverse local interests leads to a more acceptable and workable resolution of national problems. It may be argued on the other hand that the local influences in Congress are so strong that they prevent the government from dealing effectively with important national problems. ${ }^{16}$ Certainly in price control the split between the two branches of government and the lack of party responsibility has had unfortunate results. It has meant that Congress did not have complete access to the

14. The Southern Democrats in the Senate generally support a strong price control. In the House, while many Southern Democrats supported price control, many also opposed it. The key vote in the Senate was on the Dirksen Amendment, which would have eliminated price control from the Defense Production Act. Of the 28 Senators from southern and border states only one voted for the amendment, 24 voted against it and three did not vote. 98 Cong. Rec. 63333-34 (May 29, 1952). The picture in the House was different. It is illustrated by the Barden Amendment which would have ended price controls on July 31, 1952. IJot only was the amendment proposed by a Southern Congressman but out of 125 representatives from southern and border states 36, over one-fourth, voted for it. Sixty-six members voted against it and 23 did not vote. 98 Cong. Rec. 8348-49 (June 26, 1952).

15. The American Political Science Association established a Committee on Political Parties which studied this problem for four years. It concluded as follows: “. . Historical and other factors have caused the American two-party system to operate as two loose associations of state and local organizations, with very little national machinery and very little national cohesion. As a result, either major party, when in power, is ill-equipped to organize its members in the legislative and the executive branches into a government held together and guided by the party program. Party responsibility at the polls thus tends to vanish. This is a very serious matter, for it affects the very heartbeat of American democracy. It also poses grave problems of domestic and foreign policy in an era when it is no longer safe for the nation to deal piecemeal with issues that can be disposed of only on the basis of coherent programs." Towards a More Responsible Two-Party System, 44 Ax. PoL. Scr. Rev. (Supp. 1951).

16. "Now that the nation is crowded, harassed by weighty social and economic problems, and deeply involved in world affairs, better teamwork between the legislative and executive segments of government is essential to the welfare and security of the American people, and perhaps to the survival of the democratic system. . . . President Franklin D. Roosevelt summarized the situation when he said: "The letter of the Constitution wisely declared a separation, but the impulse of common purposes declares a union." " Kefauver \& Ievin, A Twentieth-Century Congress 66 (1947). 
vast body of knowledge, experience and insight accumulated by the executive department in administering the laws. ${ }^{17}$ It also has led to a strengthening of the influence of pressure groups, not strong enough to influence national policy, but strong enough to apply local pressures on enough Congressmen to secure special amendments that substantially diminished the effectiveness of price control.

The Role of Pressure Groups. - The role of the Congressman dealing with price control legislation is not a happy one. He is besieged by delegations from industries affected by price regulations; he receives telegrams and letters from scores of influential constituents; he is under constant, relentless and unceasing pressure to protect the interests of particular constituents within his Congressional district. On the other hand, he receives little pressure to vote in favor of price control except that he realizes that it will be a general issue in any campaign in which he engages. ${ }^{18}$

Lobbies exert their influence, not only because they represent groups whose members vote in a Congressman's district, but also because they contribute to Congressional campaign funds. It takes big money to be elected to Congress today and the money comes largely from people who want something special for their money. If any one thing would diminish the power of pressure groups, it would be to relieve those seeking political office from the necessity of obtaining funds from those groups. Here again the problem is easy to see, but hard to answer. The payment of some campaign funds by the government, or the raising of party funds by many small contributions instead of a few large ones, could do something to free Congressmen from financial obligations to big contributors. ${ }^{19}$

17. Congress does have some access to administrative expertise. Traditionally, after bills are introduced they are referred through the Bureau of the Budget to the appropriate executive agency for comment. There is often consultation between executive and congressional staff members. Committees receive reports and hold hearings to get the facts. However, antagonism and differences in objective tend to color the presentation of facts to Congress and to limit their acceptance by Congressmen.

18. For an excellent discussion of the role of pressure groups in government today, see Truman, The Governmental Process (1951), and Burns, Congress on TrIAL c. 2 (1949).

19. In 1951 the Douglas Committee, investigating ethics in government, gave considerable study to this problem. The committee's report stated as follows: "Conscientious candidates face the dilemma of accepting disproportionate contributions from particular groups (with corresponding obligations) or of not having enough money to make a good fight."

"Persuasive testimony has been received arguing that direct public support for political campaigns is desirable. . . Since ownership of the airways is vested in the public, it is argued, radio and television licensees should be required to make time available for discussion at stated periods during campaigns. . . Another possibility is to give the franking privilege to candidates. A third, more radical, proposal-although it is not new-is to pay from public funds to meet campaign 
The significant thing in watching pressure groups work on Congress is not that they are so successful but that Congressmen so often resist the efforts of these groups to write their own definitions of the public interest into the law. Actually on the broad general question as to whether there will or will not be price control, the lobbies have very little influence. Congressmen usually recognize that this is a general political question on which they are answerable to all their constituents.

Lobby and pressure groups are a part of the democratic process. They are one way in which Congress gets informed. But these lobby and pressure groups represent only a limited portion of all the interests, organized and unorganized, in the country. Lobbies are highly effective in securing the passage of amendments, which by making price control painless for a particular group also make it either ineffective or administratively unworkable in broad areas. The cumulative effect of these amendments may destroy the substance of the bill itself. The Herlong, Fugate, Butler-Hope and Bricker Amendments, ${ }^{20}$ which left wide gaps in price control legislation, were all the result of effective lobbies.

\section{The Defense Production Act of 1950}

However much general criticism could be directed at Congressional procedures, the final test is how well Congress does the job. In dealing with price control legislation, that judgment requires a more detailed analysis of the major problems faced by the OPS and by the Congress and an appraisal of how well Congress has handled the specific problems it faced.

Despite some deficiencies, the Defense Production Act of 1950 was generally regarded as a workable law. The basic criteria for the establishment of ceilings were the same as those prescribed in the Emergency Price Control Act of 1942, under which the Office of Price Administration had been able to run an effective program. ${ }^{21}$

The failure to impose a general freeze immediately after the enactment of the Defense Production Act in September 1950, or at least after the Chinese intervention in Korea in November, must be char-

costs of candidates or parties." Ethical Standards in Govermnent, Report of the Subcommittee of the Senate Committee on Labor and Public Welfare 82d Cong., 1st Sess. 63 (1951).

The efforts of Beardsley Ruml, in the 1952 campaign, to raise funds by small contributions from many contributors is a step in the right direction, though there can be no question that the campaign was primarily financed through the usual large contributions.

20. See pp. $355,358,365$.

21. Field, Economic Stabilization Under the Defense Production Act of 1950. 64 HaRV. L. REV. 1 (1950). 
acterized in retrospect as a very serious mistake. ${ }^{22}$ When finally the General Ceiling Price Regulation (the "freeze") ${ }^{23}$ was issued on January 26,1951 , the Office of Price Stabilization was immediately faced with some grave problems.

Price relationships in the American economy are as delicate as they are complex. The technique of the GCPR-freezing the prices of every individual seller in the country at the highest price at which he made deliveries in the period December 19, 1950-January 25, 1951 - was the only means available to stop a runaway of prices. But the unavoidable result of the freeze was the perpetuation of a price structure which was badly out of balance.

First, prices of raw materials and prices at the manufacturing and processing levels are much more sensitive and fluctuate much more rapidly than prices at subsequent levels of distribution. The impact of the post-Korean inflation (which was largely psychological in origin) was felt more sharply at the wholesale level than at retail. The Wholesale Price Index between June 15, 1950, and January 15, 1951, increased about 15 percent while the Consumer Price Index increased only 6.6 percent. ${ }^{24}$ In other words, prices at wholesale rose $21 / 2$ times faster than prices at retail.

Obviously retail prices had lagged behind wholesale prices and a normal relationship between wholesale and retail price levels could be restored only by raising retail ceilings or lowering wholesale ceilings. Retailers had to be allowed their normal margins over wholesale costs, and these normal margins could be preserved only by lowering those wholesale costs, or by raising retail prices.

Second, there were cases where, within a given industry, some sellers had complied with the government's request to hold the line made in December, 1950, and had either absorbed cost-increases without increasing prices or had at least not increased prices faster than their costs had increased. Others had charged all the traffic would bear. These sellers, the patriotic and the less patriotic, all had their prices frozen indiscriminately. It was obviously inequitable to penalize sellers for their patriotic conduct by allowing higher ceilings to their less responsible competitors.

22. Ginsburg, Price Stabilization, 1950-2: Retrospect and Prospect, 100 U. oF PA. L. Rev. 514 (1952).

23. 16 FED. REG. 808 (1951).

24. The BLS Wholesale Price Index on June 15, 1950, was at 100.2 $(1947-9=100)$. On January 15,1951 it was at 115 . The BLS Consumer Price Index was at 170.2 on June 15,1950 , and at 181.5 on January $15,1951 \quad(1935-9=$ 100). 
Third, prices of some commodities had risen more rapidly than the prices of other commodities, or of wages, to which they bore a certain normal relationship. This was important for two reasons. Every price in the economy is someone else's cost. If the price of aluminum increases, for example, the manufacturer of housewares must either raise his prices or suffer a contraction of margins. There were many instances where the prices of materials, either raw or manufactured, rose faster than the prices of commodities made from those materials. Similarly, every retail price is a wage-earner's cost. Thus, the sharp rise in the price of beef, a major cost of living item, naturally increased pressure for higher wages. Distortion of normal price relationships was also important because there might be diversion of supplies or production to more profitable channels where higher ceilings were obtainable.

It was obvious that any system of price control to be equitable or even tenable had to be based on a rectification of these distortions and a restoration of more normal relationships. To have corrected all the distortions by means of increasing the unduly low ceilings would have been inflationary. Stabilization of prices would have occurred at unduly high levels. The only alternative was a series of limited rollbacks.

This program of limited rollbacks presented the major issue in the 1951 fight over extension of the price control legislation. The easing of inflationary pressures in many commodity areas subsequent to the enactment of the 1951 amendments makes the bitter contest over some of those amendments seem in retrospect a little academic. But in appraising the Congressional approach to price control problems it is necessary to put ourselves in the context of May, June and July, 1951. At that time the upward movement of the Wholesale Price Index had been halted and even slightly reversed. But wholesale prices generally were still 14 to 15 percent higher than they were before Korea. $^{25}$ Moreover, retail prices were some 9 percent higher than before Korea, and were continuing to rise. ${ }^{26}$ There was widespread expectation in Congress and everywhere else of continued inflationary pressure. Hence, the limitations on the effectiveness of the price control authority imposed in 1951 cannot be explained in terms of a conviction that price controls were not needed.

25. The Wholesale Price Index reached a high of 116.5 in February. It was at 115.9 in May, 115.1 in June, and 114.2 in July.

26. The Consumer Price Index was at 183.8 in February, 185.4 in May, 185.2 in June, and 185.5 in July. 


\section{The 1951 Amendments}

The Capehart Amendment.-The OPS made two serious efforts to straighten out, at least to a limited degree, the badly distorted situation created by the freeze. The first was in the field of manufactured commodities generally, the second related to beef.

The Capehart Amendment grew out of Ceiling Price Regulation 22, the General Manufacturers Regulation. ${ }^{27}$ CPR 22 was designed to supersede the freeze imposed by the General Ceiling Price Regulation for most manufactured items. Its plan was simple. It continued the GCPR system of establishing separate ceilings for each individual seller. Ceiling prices were to be recalculated for manufactured products by adjusting pre-Korean prices for increases in manufacturing labor and material costs occurring after Korea.

The theory of CPR 22 was clear. To begin with, it was to be only an interim measure. Its purpose was to relieve those manufacturers whose margins were squeezed as a result of the general freeze and also to roll back the ceilings of those manufacturers who had increased selling prices more than was warranted by the increase in costs. Just as CPR 22 replaced the freeze, so it too was to be replaced by more suitable regulations, particularly dollars and cents regulations, tailored to the situations in particular industries.

Under CPR 22 there was to be as nearly as possible a restoration of pre-Korean price relationships between sellers and of pre-Korean cost-price relationships for an individual seller. To that end sellers would be compelled to go back to pre-Korean prices as a starting point in computing ceilings. An adjustment would be granted, however, for labor and material costs since all wage increases and many material cost increases could not, as a practical matter, be undone. Overhead cost increases would, on the other hand, not be recognized because of the difficulty of assigning those cost increases to individual products and because it was anticipated that they could be absorbed by expanding volume.

Where manufacturers had heeded governmental admonitions to hold the line and costs had increased faster than prices, CPR 22 was bound to result in price increases. Where, however, prices had moved up faster than costs, CPR 22 would result in rollbacks. Once CPR 22 had served to straighten out the ceiling price structure, it would be feasible to impose on a reasonable basis dollars and cents ceilings or other more tailored treatment in particular industries.

27. 16 FED. REg. 3562 (1951). Ceiling Price Regulation 30, Machinery and Related Manufactured Goods, 16 FED. REG. 4108 (1951) was a comparable regulation applicable to machinery. 
It must be conceded that experience under CPR 22 proved it to be a far from satisfactory regulation. There were a number of things wrong with it.

First, it continued the system of individual pricing used under the freeze. This made enforcement difficult. . Also it established different ceilings for sellers of the same item who in a normal economy frequently sold at the same price.

Second, the regulation led to unreasonably high ceilings in many cases. This was because several optional methods of calculating ceilings were prescribed to take care of industries characterized by seasonal fluctuations and to provide for the variety of cost accounting systems used by manufacturers. Large manufacturers, of course, made each of the optional calculations and used the one yielding the highest ceiling.

Third, the determination of ceilings required a complex series of calculations. This complexity made compliance with the regulation burdensome for small companies. It also made evasion of the regulation much harder to detect.

Fourth, the regulation with its complex calculation and filing requirements so burdened the agency's staff that they were not able to devote their energies to the development of tailored regulations for particular industries.

It is possible that CPR 22 was the only device which could have been used at the time to correct even partially the many distortions resulting from the freeze, but it is obvious from the foregoing that the regulation had many deficiencies. But whatever its merits as an instrument of price control, CPR 22 would have resulted in rollbacks for an appreciable number of manufacturers, including some large ones. Some of these companies complained bitterly to Congress. Congress heeded the complaints, rebuked the Administration for its mistake in failing to impose controls earlier and then proceeded to compound the mistake in the Capehart Amendment.

The Capehart Amendment, section 402(d)(4) of the Defense Production Act, read as follows:

"After the enactment of this paragraph no ceiling price on any material (other than an agricultural commodity) or on any service shall become effective which is below the lower of (A) the price prevailing just before the date of issuance of the regulation or order establishing such ceiling price, or (B) the price prevailing during the period January 25, 1951, to February 24, 1951, inclusive. Nothing in this paragraph shall prohibit the 
establishment or maintenance of a ceiling price with respect to any material (other than an agricultural commodity) or service which (1) is based upon the highest price between January 1, 1950, and June 24, 1950, inclusive, if such ceiling price reflects adjustments for increases or decreases in costs occurring subsequent to the date on which such highest price was received and prior to July 26,1951 , or (2) is established under a regulation issued prior to the enactment of this paragraph. Upon application and a proper showing of his prices and costs by any person subject to a ceiling price, the President shall adjust such ceiling price in the manner prescribed in clause (1) of the preceding sentence. For the purposes of this paragraph the term "costs" includes material, indirect and direct labor, factory, selling, advertising, office, and all other production, distribution, transportation and administration costs, except such as the President may determine to be unreasonable and excessive." 28

It will be seen that the first sentence, in effect, prevented rollbacks below the level of the prices prevailing after the freeze unless the market had fallen subsequently, in which case a regulation could follow the market down. The second sentence preserved existing regulations and also permitted OPS to go below freeze levels or even below current market levels if the ceiling was equal to the highest pre-Korean price plus all cost increases occurring between the pre-Korean period and July 26, 1951 (the date when the Senate and House conferees agreed to the amendment). The third sentence entitled each individual seller to an adjustment of his ceiling on individual application so that it would be equivalent to his highest pre-Korean price plus all cost increases up to July 26, 1951. The individual adjustment clause of the third sentence contained, of course, no saving clause preserving existing ceilings.

The Capehart Amendment presented to the Congress two of the most basic of price control issues: (1) the extent to which sellers should be required to absorb cost increases without increases in ceilings; (2) whether an individual seller should be subjected to ceilings which, although fair and equitable to most members of a class, nevertheless work a hardship on that individual seller because, for one reason or another, his operation is economically less efficient than that of most members of the class.

28. The amendment was added by $\$ 104(\mathrm{e})$ of the Defense Production Act Amendments of 1951, 65 STAT. 135 (1951), 50 U.S.C. ApP. $\$ 2102$ (d) (4) (Supp. 1952). Section 107 of the Defense Production Act Amendments of 1952, 66 STAT. 298 (1952), added a sentence excluding from the coverage of the Capehart provisions, wholesaler; and retailers covered by the Herlong Amendment. This language was designed to overrule Safezway Stores, Inc. v. Amall, 196 F.2d 510 (Em. Ct. App. 1952). 
The OPA in World War II had arrived at a policy on both of these issues, which OPS adopted. On the question of cost absorption, OPS rejected the notion that every cost increase should be reflected in a ceiling price increase. To be sure, the idea of allowing a seller to recover a cost increase by increasing his ceiling has a certain superficial appeal. But since every price in the economy is someone else's cost, it was obvious that unless cost absorption was required at some point there would be an indefinite escalation of prices, and that it would be impossible to control prices effectively. The standard for cost absorption worked out by OPA and adopted by OPS was the so-called earnings standard. Increased costs would not be recognized as a basis for increased ceilings unless and only to the extent that the effect of the increased costs was to depress industry (not individual) earnings below normal. A normal level of earnings was defined as roughly the excess profits tax standard-85 percent of the industry earnings for the best three of the four years 1946-9, adjusted for changes in net worth. ${ }^{28}$

OPS like OPA also operated on the theory that it must, wherever feasible, establish uniform ceilings for all sellers in an industry at a point which would be fair to the bulk of the sellers in that industry, even though those ceilings might work hardship on a few high cost sellers.

The reasons for this policy were fairly obvious. Uniform ceilings were essential to effective enforcement of the regulations. Individual ceilings for hundreds of thousands of sellers made the task of checking violations insuperable. To set uniform ceilings at a level high enough to take care of the highest cost producer would have meant impossibly high ceilings inconsistent with a serious stabilization program. On the other hand setting ceilings at a point which covered the bulk of the sellers in an industry was in effect following the pattern of a normal economy where the marginal producers, characterized by inefficiency, had either to improve their operations or withdraw from the competitive struggle.

Both of these decisions are hard ones and neither of them appealed to Congressmen generally. In rejecting these decisions, Congress turned 180 degrees the other way and adopted an approach to price control which can only be characterized as inflationary and as technically wrong.

29. The OPS industry earnings standard was first announced in a letter, dated April 21, 1951, from Eric Johnston, Administrator of the Economic Stabilization Agency, to Michael V. DiSalle, Director of the Office of Price Stabilization. It is spelled out in OPS Price Operations Memorandum No. 25, dated February 15, 1952. For a discussion of the OPA industry earning standard, see PROBLEMS IN PRICE Control: Pricing Standards, $C_{\text {H. }}$ II, The Industry Earnings Standard, (Office of Temporary Controls 1947). 
First, the limitations on, in effect prohibitions against, rollbacks precluded stabilization of prices except at a level much higher than that which had theretofore been possible. Superficially, for example, the first sentence of the amendment permitted stabilization of prices at the GCPR levels. But actually because no ceilings could be established below GCPR levels, other ceilings would have to be established at higher than GCPR levels to avoid squeezes and inequities.

Suppose for example, that at the time of the freeze the spread between wholesale and retail prices of widgets was less than normal. Since wholesale prices could not be rolled back below freeze levels because of the Capehart Amendment and since other provisions of the law required maintenance of normal margins, the practical impact of the Capehart Amendment was to require raising retail prices of widgets above freeze levels.

Second, CPR 22 had established December 31, 1950 as the cutoff date beyond which most material cost increases would not be recognized and March 15, 1951 as the cutoff date for labor cost increases and for a few material cost increases. The third sentence of the Capehart Amendment by guaranteeing a seller an automatic pass through of all cost increases up to July 26, 1951, was bound to continue the upward movement of prices beyond the point where they reasonably might have been stabilized.

Third, by guaranteeing each seller an individual price based on all cost increases, the amendment precluded in many areas the possibility of uniform dollars and cents ceilings. It thus gave to an individual seller in time of shortage an advantage which the competitive workings of a free market ordinarily denied him-the advantage of being able to sell at a price higher than that established for a competitor. Moreover, the inability to impose uniform dollars and cents ceilings made enforceable price control difficult in many areas.

Thus, the system of individual pricing, which OPS had adopted in the GCPR and CPR 22 as a temporary expedient, was frozen into the law by the amendment. There was imposed on OPS for all industrial commodities a system of individual pricing with its corresponding administrative burdens which was, to say the least, impractical.

Fourth, the Capehart Amendment was written on the assumption, which every accountant knows to be erroneous, that overhead costs of a multiproduct company can readily be assigned to individual products, and on the further assumption, likewise erroneous, that American businessmen generally keep the kind of cost records which would per- 
mit such an assignment, even if it were theoretically feasible. ${ }^{30}$ The regulations which OPS eventually adopted to implement the amendment were as a result models of complexity-a complexity which the statute made unavoidable. ${ }^{31}$

The Capehart Amendment was, in sum, inconsistent with workable price control. The amendment did not lay down any reasonable policy on cost absorption. And certainly regardless of what policy was followed on cost absorption, it is hard to find a justification for a policy of mandatory individual pricing.

Moreover, the psychological impact of the Capehart amendment on subsequent OPS policy was bad. Many high ceilings were not reduced, even though it was legally feasible, because of Congressional antipathy to rollbacks. Certainly in some of the areas where a suspension policy was followed because prices were below ceilings, it would have been more suitable to roll back ceilings instead.

The issue presented by the CPR 22 rollbacks was clearly of such general importance that Congress properly decided that the matter should be resolved by it rather than by OPS. There can be no quarrel with the fact that Congress decided the issue but only with the substance of the decision, for the reasons already indicated, and with the way in which Congress approached the problem.

No provision like the third sentence of the Capehart Amendment was ever presented to or discussed by either the Senate or House Banking and Currency Committee or by the full Senate or House. It first appeared after both the Senate and the House had acted on extension legislation in post-midnight sessions of the Conference Committee. It was presented in a situation where the Committee was considering a long and complex series of amendments and was rushing to get a bill to the President before the legislation expired. The Committee did not have the benefit of full consideration and expert advice by its own staff, because that staff did not have adequate opportunity to look into the problems presented by the unexpected suggestion presented in the third sentence of the Capehart Amendment.

The necessity of operating under a deadline not only deprived the Conference Committee of the opportunity for careful consideration of the Capehart Amendment but the normal wear and tear of a long and

30. See Statement by Michael V. DiSalle, August 30, 1951, prepared for submission to Senate Banking and Currency Committee, pages $3-4$, and Hearings before Senate Committee on Banking and Currency on S. 1928, S. 2092, and S. 2104, 82d Cong., 1st Sess. 2834, 2837 (1951).

31. See Supplementary Regulation 17 to Ceiling Price Regulation 22, 16 FED. Reg. 11484 (1951), Supplementary Regulation 18 to Ceiling Price Regulation 22, 16 FED. REG. 11919 (1951), General Overriding Regulation 20, 16 FED. REG. 12014 (1951), and General Overriding Regulation 21, 16 FED. REG. 12310 (1951). 
hurried session naturally wore down the patience of the Committee members and produced an atmosphere conducive to the adoption of any plausible compromise no matter how ill-considered. Moreover, the OPS proved itself something less than politically astute when by successive postponements it fixed the effective date of the CPR 22 rollbacks on July 2, thus diverting from itself to Congress all the political heat generated by industry against the rollbacks.

That the Conference might well have rejected the third sentence, had it been fully aware of its significance, is best indicated by the fact that in the fall of 1951 both the Senate and House Banking and Currency Committees, after they had adequate opportunity to consider the matter, reported out favorably bills modifying the Capehart Amendment by revising the individual adjustment clause and by permitting the establishment of uniform industry-wide ceilings at the levels prescribed in the first two sentences of the Capehart Amendment. ${ }^{32}$

The merits of the first two sentences of the Capehart Amendment, although they represented a blow to the stabilization program, are at least arguable. But in any period of acute inflationary pressure, elimination of the third sentence would be essential to effective price control. The third sentence of the Capehart Amendment was thus an off-the-cuff disposition of an important and complex problem in a situation where Congress was compelled to act hastily without expert assistance.

The Fugate Amendment.-The fight over the beef rollbacks involved the same fundamental issue. ${ }^{33}$ In the period following Korea, cattle and beef prices had increased much more rapidly than prices generally. Before Korea the average farm price of cattle had been $\$ 23.70$ per cwt. On January 15,1951 , it was $\$ 27.00$ per cwt. The freeze arrested the upward movement of beef prices at wholesale and retail but a freeze technique would not work for cattle and controls on cattle were not issued until April 30. By April 15, the average farm price of cattle had risen to $\$ 30.20$ per cwt. or 152 percent of parity.

In the period between January 1950 and April 1951 cattle prices rose five times as much as the wages of manufacturing workers, over four times as much as the prices paid by farmers, over five times as

32. See Sen. Rep. No. 796, 82d Cong., 1st Sess. (1951) ; H.R. Rep. No. 1186, 82d Cong., 1st Sess. (1951). See also, Hearings before the Sentate Committee on Banking and Currency on S. 1928, S. 2092, and S. 2104, 82d Cong., 1st Sess. (1951) and Hearings before the House Committee on Banking and Currency on $S .2170$, 82d Cong., 1st Sess. (1951). The bill modifying the Capehart Amendment, S. 2170, passed the Senate, but never got out of the House Rules Committee. S. 2170 did contain a clause requiring relief for individual hardship. However, the principle of uniform industry-wide pricing was substantially restored.

33. For a full discussion of the OPS position on the cattle rollbacks, see the Memorandum on the Beef Control Program, June 8, 1951, in Hearings before the House Committee on Banking and Currency on H.R. 3871, 82d Cong., 1st Sess. 1280 et seq. (1951). The factual material used here is taken from that memorandum. 
much as consumer prices, and over three times as much as the prices of food items generally.

Cattle prices in turn were, of course, the key to beef prices. The farmer gets approximately 70 cents of the consumer's beef dollar. Since margins of packers and retailers do not account for a major portion of the retail price and since the element of profit in those margins is not large, even a squeeze on margins would not result in a significant reduction of retail beef prices.

On the other hand the need for a significant reduction of beef prices in order to restore normal pre-Korean price relationships was obvious. Moreover, the need was particularly acute because of the importance of beef in the cost of living and because of its psychological significance in the stabilization program. Beef has a weight of almost 12 percent in the food index of the Consumer's Price Index and a weight of over 4 percent in the over-all Consumer's Price Index. Moreover, the rapid increase in beef prices after Korea became the very symbol of inflation. Finally there could be no doubt that the increase in beef prices was an important economic factor and an even more important emotional factor in increasing pressure for wage increases.

The indicated course for the Office of Price Stabilization was, therefore, to attempt to roll back cattle prices to more normal levels and to make corresponding reductions of wholesale and retail beef prices. It is a tribute to Mr. DiSalle's courage that, fully realizing the political storm which would break over his head, he embarked on a program of cattle rollbacks.

The rollbacks were to be in three stages. ${ }^{34}$ There was first an initial rollback of cattle prices to approximately January, 1951, levels, a reduction of about 10 percent from the April highs. This rollback was effective one month after the issuance of the regulation. However, it did not permit a reduction of beef prices. This was because beef prices had been frozen as of the end of January, 1951, but cattle prices had not. Between January and April, cattle prices had risen about 10 percent. As a result, the spread between the prices packers paid for cattle and the prices they could legally charge for beef had been wiped out. Beef slaughtering operations were being conducted at a loss. Hence, the initial rollback served only to restore packer margins. Had it not been placed in effect, margins would have had to be restored by a further increase in wholesale and retail prices.

A reduction in beef prices was to follow upon the two subsequent cattle rollbacks to become effective in August and October. These two

34. Ceiling Price Regulation 23, 16 FEd. REg. 3696 (1951). 
subsequent rollbacks amounted in total to an additional 10 percent reduction in cattle prices, and would have made possible a reduction of retail beef ceilings averaging about 10 cents a pound.

The rollbacks were postponed because feeders had bought cattle for feeding based on the higher levels prevailing between January and April. By October substantially all cattle bought prior to announcement of the rollbacks would be out of the feedlots and the rollbacks could be put into effect without hardship to feeders. However, to lessen the impact of the subsequent rollbacks on the market they were to be made in two steps-half in August and haif in October.

The furious attack which followed this action was based really on one ground only-the unfairness of taking from cattle producers, both growers and feeders, the high prices which had been reached by April, 1951. The emotional reaction of the cattle producers was that OPS bureaucrats were taking from them what was rightfully theirs.

But in all the sound and fury which followed the announcement of the beef rollbacks there was never a demonstration that the prices which would prevail after the last rollback were unfair or were insufficient to encourage production. In the nature of the case there could not be. Cattle prices after the last rollback would have been more than 120 percent parity. By definition parity represents a fair price to the producer, and parity for beef cattle had been revised substantially upward pursuant to the Agricultural Act of $1948 .^{35}$ Moreover, cattle prices after the last rollback would still have been 25 percent higher than the January, 1950, price and 7 percent higher than the highest price which had ever prevailed before Korea.

It is understandable, however, that Congress by the enactment of the Fugate Amendment banned the August and October rollbacks. ${ }^{36}$

35. The difference made by the change in the parity formula in the parity price for beef cattle is indicated by the fact that under the new formula the parity price for beef cattle as of January 15, 1952, was $\$ 21.10$, whereas under the old formula it would have been $\$ 15.00$. See the Parity Handbook, Sen. Doc. No. 129, 82d Cong., $2 \mathrm{~d}$ Sess. 5 (1952).

36. The amendment prohibited the beef rollbacks by the device of establishing an additional legal minimum for agricultural commodities. Until the Fugate Amendment the legal minimum for an agricultural commodity was the higher of the parity price or the highest price received by producers during the period May 24-June 24, 1950. Under the Fugate Amendment the legal minimum was the higher of the parity or the May 24-June 24 price or 90 per cent of the price received (by grade) on May 19, 1951. May 19 was picked because it was the day before the originally announced effective date of the first beef rollback. The 90 per cent figure was used to permit the initial 10 per cent rollback to remain effective.

A ceiling for an agricultural commodity may not be lower than the legal minimum. Ceilings for commodities processed from agricultural commodities must "reflect" that minimum, that is, they must permit processors to pay the legal minimum for the agricultural commodity and still realize a fair and equitable margin. The legal minimum provisions of the Act will be found in $\$ 402(\mathrm{~d})(3), 64$ STAT. 805 (1950). The Fugate Amendment was added to $\$ 402(d)(3)$ by $\$ 104(\mathrm{~b})$ of the Defense Production Act Amendments of 1951, 65 STAT. 134 (1951), 50 U.S.C. ApP. $\S 2102$ (d) (3) (Supp. 1952). 
These rollbacks were taking something away from one group in the population, cattle producers, and giving it to another, consumers. Whatever the larger considerations of policy and of equity, it was obviously easier to deny to one group a prospective benefit than to take from another group a benefit which it had already obtained. That this was a significant if not dominant factor in the Congressional psychology is indicated by the fact that in the House of Representatives an attempt to knock out the initial and already effective rollback of cattle prices to January, 1951, levels was beaten back when it was made clear that this might mean raising retail beef ceilings another 10 cents a pound.

It was perhaps asking too much of Congress, given the strength of the farm bloc, to expect that it would sanction the rollbacks. The consumer, as a result, paid in higher beef prices for the failure to impose controls promptly in the fall of 1950.

The discussion above of the Capehart Amendment indicates the difficulty faced by Congress in having to deal with complex economic issues without time for adequate consideration and without the full benefit of expert assistance. The Fugate Amendment illustrates another difficulty - the unrelenting pressure placed on Congressmen by lobbies for particular groups. There can be little doubt as to how the country would have voted had the issue of the rollbacks been submitted to a popular referendum. Likewise, for the reasons stated above, there could be little serious challenge to the fairness of the beef rollbacks. Yet the beef rollbacks were voted down in both the Senate and the House by very substantial margins.

The votes on the beef rollbacks demonstrate once again the validity of an old truism about the legislative process, namely, that on occasion neither the merits of the case nor an unarticulated popular preference will prevail against the organized pressure of powerful lobbies. The cattlemen's lobbies were able in the fight on the beef rollbacks to enlist the aid of the larger farm organizations. As a result the beef rollbacks became a farm bloc issue. Accordingly, for example, many Southern Congressmen, coming from states where their constituents were consumers rather than producers of beef, voted against the rollbacks because of the tacit alliance of all farm state (including cotton state) Congressmen on issues involving farm prices. ${ }^{37}$

37. The power of the farm bloc in Congress is disproportionate to the number of farmers in the country as a whole because of the equal representation of each state in the Senate and because state legislatures, usually dominated by rural legislators have given less weight to urban than to rural areas in establishing Congressional districts. 
The Butler-Hope Amendment.-The beef rollbacks presented a relatively simple problem and the disposition of it, even though unsatisfactory from the point of view of price control, was nevertheless an understandable balancing by Congress in the light of the psychological realities, of the conflicting interests of farmers and consumers.

The Congressional banning of slaughter quotas was, however, a much less defensible decision because it was based on a lack of understanding of the problem-a lack of understanding for which the staff of OPS must bear some share of the responsibility because they never succeeded in explaining clearly and effectively the need for quotas.

The slaughter quota system had been used on an on-and-off basis in the latter stages of OPA. ${ }^{38}$ It was the first meat control imposed by the Office of Price Stabilization. ${ }^{39}$ It was issued two weeks after the general freeze and almost three months before the issuance of dollars-and-cents ceilings on cattle and beef. ${ }^{40}$

The basic features of the slaughter quota system were simple. In general each slaughterer was limited to the slaughter of the same proportion of the total available supply of a species of livestock (cattle, hogs, calves or lambs) which he had slaughtered during 1950. This limitation was accomplished by quotas established monthly. A slaughterer's quota in a given month was a stated percentage, more or less than 100, of his slaughter in the corresponding month of 1950. Thus, if, at the end of April, total hog marketings for May, 1951, were estimated to be 110 percent of the marketings for May, 1950, each slaughterer's quota was 110 percent of his slaughter in May, 1950. Where marketings during the month were higher than estimated, the quota percentage was increased. There were additional provisions limiting but not prohibiting entry into the business, and providing for adjustment of quotas.

38. Studies in Food Rattoning, Part VI, Livestock Slaughter Controls, (Office of Temporary Controls 1947).

39. The slaughter quota system was embodied in Distribution Regulation 1,16 FED. REG. 1273 (1951). DR 1 was issued not under the price control power granted in Title IV of the Defense Production Act, but pursuant to the allocation authority granted in $\$ 101$ of that Act, 64 Stat. 799 (1950), 50 U.S.C. ApP. \$2071, Supp. 1952 which, with respect to food, was delegated by the President to the Secretary of Agriculture, Executive Order 10161, 15 FED. REG. 6105 (1950), and in turn redelegated with respect to meat to the Administrator of the Economic Stabilization Agency by Delegation of Authority with Respect to the Allocation of Meat, 16 FED. REG. 1272 (1951), and in turn redelegated to the Director of Price Stabilization by ESA General Order 5, 16 FED. REg. 1273 (1951). See also, Delegation of Authority with Respect to Meat, as amended, 16 FEn. REG. 11620 (1951), and ESA General Order 5, Revision, 16 FED. REg. 11875 (1951).

40. DR 1 was issued on February 9,1950. The dollar and cents ceilings on cattle (Ceiling Price Regulation 23), on beef sold at wholesale (Ceiling Price Regulation 24), on beef sold at retail (Ceiling Price Regulations 25 and 26) were not issued until April 30, 1951. 16 FED. REG. 3696, 3721, 3739, 3704 (1951). 
The slaughter quota system had a number of important advantages but the most important single one was in making the cattle ceilings more workable. There was a general conviction on the part of those who had dealt with meat price control under OPA that the cattle ceilings would not work without quotas. This conviction was due to the peculiar nature of the cattle ceilings.

The worth of a beef animal depends on two things-its quality (grade) and the amount of meat it will yịeld when slaughtered. However, there is no reliable way to determine the grade and yield of a live animal. Grade and yield can only be determined after slaughter. For that reason OPS did not place a ceiling on the individual animal. The ceilings instead were limits on what a slaughterer might pay for all cattle slaughtered during a month. The limits were determined in accordance with a fairly complicated formula, the principal element of which was the grade of the meat derived after slaughter. In effect the price which could be paid for an animal was determined by its worth after slaughter. Because this worth could not be determined precisely for each individual animal or lot, it was necessary to put the cattle ceilings on a monthly compliance basis so that a slaughterer could average out his purchases over that period.

Because there was no ceiling on the individual animal there was no ceiling on the seller. Also, because there was no ceiling on an individual animal, slaughterers might pay what they wanted for a lot of cattle. They would still be in compliance with the regulation if their purchases balanced out at the end of the month.

It is not practical under ceilings of this type to police individual purchases since no individual purchase is a violation of the regulation. Hence it was possible for one or more slaughterers to bid up the price beyond compliance limits in a particular market and other slaughterers had either to pay the price or withdraw from the bidding.

The quota system made the compliance ceilings workable by operating as a limit on the volume of livestock for which any slaughterer could bid and as an assurance to each slaughterer that he would obtain his normal share of the total available supply without bidding up the price.

Unfortunately the OPS had failed wholly to get this point across when the Butler-Hope Amendment banning quotas had been under consideration when the Defense Production Act was up for extension in June and July. The quota system was defended primarily on the ground that it was necessary to keep out potential black marketeers who had invaded the business during OPA. ${ }^{41}$ 
However, both the Senate and House, after debate characterized by serious misunderstanding on both sides, adopted by overwhelming votes the Butler-Hope Amendment banning quotas. OPS arguments about the danger of an invasion of the business by black marketeers were met by permitting continuation of the registration or licensing program, although that was clearly not enough to prevent violations of the cattle regulation and subsequent violations of the beef ceilings.

The adverse effect of the ban on slaughter quotas was felt in the late summer and fall of 1951, when pressure on the cattle market led to widespread evasion of cattle and beef ceilings and forced legitimate slaughterers to reduce their kill sharply because of inability to get cattle at ceiling prices. During the fall of 1951 the pressure on cattle ceilings became so heavy that the Office of Price Stabilization was forced to relax the cattle ceilings for slaughterers whose kill was substantially below normal. ${ }^{42}$ The alternative would have been to force temporary shutdowns of some slaughtering establishments. To halt the widespread violations of the cattle ceilings, it was necessary also to concentrate a major part of the enforcement staff on the cattle program.

The situation became so bad that serious consideration was given within the Administration to abandoning the dollars-and-cents cattle and beef ceilings. Largely because of the firmness under fire of Mr. DiSalle, OPS was able to ride out the storm. A subsequent easing of the pressure on cattle and beef ceilings has made the inability to impose slaughter quotas academic in 1952.

The slaughter quota fight was lost largely because of the lack of proper liaison between Congress and the OPS. It is true that the cattle lobbies were very active in the fight on quotas. As in many other cases where people are in a seller-buyer relationship, cattlemen are suspicious of packers. Congressmen, particularly farm bloc Congressmen, share that suspicion. It is not surprising that some credence was given to the cattlemen's charge that packers were using or could use quotas to drive down cattle prices.

But the weight of the cattle lobby on the slaughter quota issue was much less than its weight on an issue like the beef rollbacks, which clearly and directly affected the producer's pocketbook. In this instance a very significant factor was the lack of confidence in OPS on the part of Congress generally. This in turn was not attributable to any particular hostility to the OPS personnel as such. Mr. DiSalle was both respected and liked as a man of integrity, of moderation and

42. Amendment 2, 16 FED. REG. 9075 (1951) and Amendment 4, 16 FED. REG. 10017 (1951) to Ceiling Price Regulation 23. 
of practicality. There was nevertheless a Congressional suspicion of bureaucrats and of bureaucratically imposed restraints on the free market.

This suspicion was reinforced with respect to slaughter quotas by the Congressional propensity to generalize from cases of alleged individual hardship presented by constituents. There were many complaints to Congressmen, in large measure unwarranted, about unfair administration of the slaughter quota program. In the absence of continuous liaison between Congress and the OPS there was no opportunity to dispel the Congressional hostility aroused by these complaints.

Had there been a system of continuous liaison between Congress, through its Committees and the OPS, the need for quotas could have been explained very persuasively to many Committee members at the inception of the program. The prestige of the Committees in turn might have been sufficient to save the program from the onslaughts of its opponents on the floors of both Houses.

It is significant that those who dealt most directly with OPS and who followed its activities most closely, the members of the two Banking and Currency Committees, were in the majority in favor of the slaughter quota program. The difficulty was that they were not sufficiently familiar with the need for it to push the issue vigorously when it came up on the floor. Better liaison with the Committees in the actual formulation of policy might have resulted in this familiarity.

An effort to repeal or modify the Butler-Hope Amendment was made in the fall of 1951 . The Senate Banking and Currency Committee reported out favorably a provision restoring slaughter quota authority but containing assurances that the authority could not be used to limit marketings. ${ }^{43}$ This compromise had the active support not only of the Democratic majority but also of the senior Republican on the committee, Senator Capehart. However, the Committee was unable to get the bill on the floor.

The Herlong Amendment.-The Herlong Amendment, § 402(k) of the Defense Production Act, ${ }^{44}$ provided in relevant part as follows:

43. The Butler-Hope modification was embodied in S. 2180 , accompanied by SEN. Rep. No. 840, 82d Cong., 1st Sess. 89 (1951). See also Hearings before the Senate Committee on Banking and Currency on S. 1928, S. 2092, and S. 2104, 82d Cong., 1st Sess. (1951).

44. The amendment was added by section 104(h) of the Defense Production Act Amendments of 1951, 65 STAT. 134. Several changes were made by section 110 of the Defense Production Act Amendments of 1952, 66 STAT. 299, 50 U.S.C. APP. $\$ 2102(\mathrm{k})$, the principal one being the deletion of the words "shall hereafter be issued" and the substitution of the words "shall be issued or remain in effect." The Herlong Amendment thus is now applicable to all OPS regulations, regardless of when issued. However, the Cole Amendment giving each individual wholesaler and retailer his customary markup, although passed by the House, 98 Cong. Rec. 8196, (June 25, 1952) 8346 (June 26, 1952) was rejected by the Conference Committee, H.R. Rep. No. 2352, 82d Cong., 2d Sess. 19-20 (1952). 
"No rule, regulation, order or amendment thereto shall hereafter be issued under this title, which shall deny to sellers of materials at retail or wholesale their customary percentage margins over costs of the materials during the period May 24, 1950, to June 24,1950 , or on such other nearest representative date determined under section 402 (c) . . ."

In order to understand this provision, it is necessary to refer briefly to the pre-Herlong OPS policy on distributors' margins. That policy is perhaps best set forth in the Statement of Considerations for Ceiling Price Regulations 14, 15 and 16, the regulations establishing markups for wholesalers and retailers of dry groceries. ${ }^{45}$

The markups used were expressed in percentages. But although percentage markups were used as a matter of technique, the standard by which the validity of the markups could be tested was, according to OPS, whether they yielded an amount equal to pre-Korean dollarsand-cents markups.

Again, in the case of automobiles OPS increased prices at the manufacturing level, but permitted retailers to pass through only the dollar and cent amount of the increase. ${ }^{46}$ This policy became one of the major targets in the 1951 legislative battle. Retail representatives attacked OPS for interfering with customary pricing practice in the distributive trades. ${ }^{47}$

The attack failed to impress either the Senate or House Committee. No provision on distributors' margins appeared in the bills sent to the Senate and House floors. ${ }^{48}$ When, however, the extension legislation came up on the House floor, the House adopted an amendment requiring OPS to give each individual distributor his customary percentage markup. ${ }^{49}$ There was no such provision in the bill passed by the Senate and the issue came up in conference. The conference compromise was a substantial improvement over the House bill because the requirement of giving each individual distributor his customary markup was deleted. Customary percentage margins for a class of

45. 16 FED. REG. 2725 et seq. (1951).

46. Amendment 1 to Supplementary Regulation 5 to the General Ceiling Price Regulation, 16 FED. REG. 2151 (1951).

47. See e.g., testimony of Rowland Jones, Jr., President of the American Retail Federation, Hearings before the Senate Committee on Banking and Currency on S. 1397, 82d Cong., 1st Sess. 2019 et seq. (1951) and of Charles C. Freed of the National Automobile Dealers Association, Id. at 2103 et seq.

48. The Senate Committee expressly took cognizance of the retailers' complaints but refused to take statutory action to deal with them, confining itself to a statement that OPS must consider increases in retailers' operating expenses in fixing margins. SEN. REP. No. 470, 82d Cong., 1st Sess. 15 (1951).

49. 97 Cong. Rec. $8740-5$ (July 20, 1951). 
distributors were required instead to be given to each distributor in the class. ${ }^{50}$

Apart altogether from its inflationary effect, the Herlong Amendment was based on oversimplified assumptions as to the facts. Customary percentage margins in the distribution trades, in the sense of stated percentage margins (1) realized by most sellers in a particular class and (2) realized over a period of time long enough to warrant use of the word "customary," are largely a myth. The fact is that, although many distributors, as a matter of pricing technique, establish prices by adding a percentage markup to their cost of materials, the amount of the markup very often varies substantially from distributor to distributor at any given time and varies substantially for any given distributor from time to time.

Congress nevertheless adopted an amendment requiring OPS to provide distributors with their customary percentage margins "during the period May 24, 1950, to June 24, 1950." As applied to specific states of fact, even the very language of the Herlong Amendment is confusing. Most sellers do not have constant percentage margins over long periods of time. Hence, the particular percentage margin which happened to prevail "during the period May 24, 1950, to June 24, 1950 " was not a customary percentage margin within the intent of the law. Moreover, in many cases, the margin which was customary, that is the margin which prevailed over a long period of time, was not a percentage margin.

But even accepting the argument that there were customary percentage margins in the distribution trades and that those margins were determinable, it is obvious that to require OPS to follow this custom in a period of rising prices was inconsistent with effective price control. If, as was true in many cases, prices at the manufacturing or processing level rose faster than operating expenses at the distribution level, percentage margins were bound to provide much more than normal earnings.

Moreover, the Herlong Amendment required maintenance of percentage margins with a rising price level even though volume increases were reducing unit operating expenses. Even dollar margins may be inflationary in a period where sharp increases in volume may reduce the unit cost of doing business very substantially. Percentage margins were obviously that much more inflationary.

The inflationary effects of the Herlong Amendment forecast by OPS failed to materialize to the extent predicted for several reasons. First, and most important, the burden of showing customary margins

50. H.R. REP. No. 770, 82d Cong., 1st Sess. 25 (1951). 
was placed on sellers rather than OPS. Second, specific studies showed that in some instances the customary margin pattern was dollars and cents rather than percentage margins. Third, in some cases technical considerations dictated the use of percentage rather than dollars and cents margins, and in other cases operating costs increased at a rate which would have required the use of percentage margins as a matter of fairness and equity, apart altogether from Herlong.

But, although the ultimate impact of the Herlong Amendment has not been as grave as OPS at first believed, it has been serious enough. To conform to the amendment, distributors' margins have been increased in many cases beyond the level which would be required to assure normal earnings. As a result, the cost of living has been increased by more than would otherwise have been the case.

\section{The 1952 Legislation}

The 1951 legislative fight had been largely concerned with the character of the controls which OPS might impose. The 1952 fight centered on the question of whether controls were needed at all. ${ }^{51}$

The ambiguous economic situation did not present a clear-cut case for continuance of controls. On the other hand, it was clearly the part of prudence not to scrap controls hastily in a period when they might be needed badly as a result of an unfavorable turn in the international situation and when they were clearly doing some good in some areas, most notably in the field of items needed for the procurement program.

In a general sense, the 1952 fight over extension and amendment of the price control provisions of the Defense Production Act in 1952 presented the question of whether widespread regulation of the economy is justified under the economic conditions prevailing in 1952. Where the danger of overpowering inflation was clear, Congress had not hesitated to authorize sweeping direct controls to stabilize the level of prices, wages and rents. It did so during World War II. It enacted comprehensive legislation providing for similar controls in September 1950, within three months of the outbreak of the Korean War, when the dangers of inflation were clear even though the Administration itself had not yet requested price control authority.

51. Renewed efforts to get the Capehart, Herlong and Butler-Hope Amendments repealed or changed were made in 1952. Message from the President of the United States, H.R. Doc. No. 347, 82d Cong., 2d Sess. 4 (1952). However by that time, the economic situation had changed drastically. The case for repeal or modification of the amendments was just as strong in terms of price control policy but it was not as urgent as a practical matter. As a result these amendments were not a serious issue during the consideration of the 1952 legislation. 
In 1952, however, the economic situation was ambiguous. True, the underlying ingredients of inflation were still present. On March 31,1952 , the gigantic post-Korea defense program was only one-quarter completed. Expenditures for national security were increasing and were taking a larger share of the annual output. ${ }^{52}$ Liquid savings were at a record high. A sudden release of these savings in the market place and another panic buying spree, which could be caused by new international developments, would generate terrific pressure on prices. The Consumer Price Index had reached near record highs, increasing almost 14 percent since Korea. In many important areas, prices were pushing the ceiling and, if price stabilization were abolished, would rise even more. This was particularly true in the heavy industry areas related to the defense program. But it was also true of other commodities, including such basic foods as milk and bread. Finally, a turn for the worse in the international situation could easily lead to scare buying, shortages, and rapidly rising prices.

There was another side of the picture. Even the staunchest advocate of direct price control would concede that it should be used only as a last resort. In many areas, sensitive marketing mechanisms do not lend themselves readily to the arbitrary flat-footed techniques of price control. Over the long run, the proper level of prices cannot be determined on the basis of the judgment of price administrators no matter how objective or competent. Moreover, even setting aside these more serious considerations, price control means red tape for businessmen, discriminates against small sellers who are unable to understand or take full advantage of the regulatory mechanism, and causes understandable and mounting irritation by businessmen who are prevented from doing what they want by government regulation. Congress has always been sensitive to the underlying dangers of longrun price control. Moreover, because of the pressure of its constituents, it has become almost over-aware of the irritations and red tape that are inevitable under price control no matter how well administered.

The proponents of price control, therefore, have to overcome the presumption that price controls are undesirable by showing that they are clearly necessary. In 1952 this showing was difficult to make. While

52. Before Korea, national security expenditures were at an annual rate of less than 17 billion dollars-about 6 percent of the national output. In the first quarter of 1952 , security expenditures had climbed to a rate of about 47 billion dollars, or nearly 14 per cent of the national output. It was expected that by sometime in 1953, this security expenditure rate would increase to some 65 billions-about 18 per cent of the annual output. Thus, while the price control legislation was under consideration, it was expected that the impact of an increase of 15 or 20 billion dollars in annual security expenditures was still to hit the economy. 
the general ingredients of inflation were present, while prices were high, and while in many areas prices were pressing ceilings, there were on the other hand widespread indications that in some areas price controls were not necessary. Particularly in durable and soft goods there was evidence that many major commodities were selling below ceiling and that the inflationary pressures would not push up prices. In these areas, Congress was faced with the paradox that while purchasing power was at an all-time high and while the cost pressures that lead to inflation were increasingly insistent, consumer demand had slackened. There was substantial evidence that no matter whether price controls were to continue, prices in these areas would not increase. The OPS itself had recognized this fact, had established standards for suspension of controls in these soft market areas, and had suspended controls in significant areas.

In the background was the disastrous steel controversy. The House and the Senate Banking and Currency Committees held extensive investigations of this controversy while they were considering extension of the law. It is, of course, beyond the scope of this article to discuss the merits of that controversy. There can be no question, however, that a large number of Congressmen felt that the Wage Stabilization Board had granted the steel workers an amount in excess of that to which they were entitled under sound stabilization standards, and that the price control standards of the Office of Price Stabilization in dealing with steel were too rigid. Those accepting this sentiment felt either that the administration of controls was so unfair that they should not be continued in a situation where the need for them was not clear or that the pressure which was generated by an over-generous wage stabilization policy made price control ineffectual. Most Congressmen, even those who shared these sentiments, were not inclined however to take the chance that prices would not go up if controls were lifted. But, the feelings aroused by the steel case were partially responsible for the resentment shown by the House of Representatives in passing a price control bill which contained such substantial amendments as to be worthless.

On balance, however, Congress decided to retain controls, primarily because it felt that it could not take a chance when the underlying factors leading to inflation were still present and when the international situation was still so turbulent. But in doing so, it passed a series of amendments limiting the authority of the Office of Price Stabilization, and indicated its clear desire that in those areas where the facts did not warrant control the OPS was to suspend those controls. 
The ultimate approach of Congress was, on the whole, statesmanlike. It recognized that controls might well be needed in the future. It also recognized that automatic decontrol and suspension formulas would not work, and so attempts to write these into the law did not succeed. But it is not unfair to say that this approach succeeded because of the leadership of the Senate Banking and Currency Committee in the Senate and of the ability of that leadership to make its views prevail in conference.

Despite the fact that its Banking and Currency Committee reported out a workable bill, the House action on price controls was to preserve the form of controls but not the substance. To strike down controls entirely, although it might have been wrong, was at least a consistent and tenable approach. To establish controls on a standby basis was also a possible approach. To strengthen and extend the price control authority, even if an arguable course of action, was at least a rational one. But to pass a completely gutted price control bill was certainly not a reasonable discharge of legislative responsibilities.

The Harrison Amendment.-By far the most important of the changes made in the 1952 bill was the Harrison Amendment, which prohibits price control on fruits and vegetables in fresh or processed form..$^{53}$

This provision arose in the first instance in the fight over potato price control. As adopted on the Senate floor and in the House Banking and Currency Committee, it prohibited price control on fresh fruits and vegetables. ${ }^{54}$ However the amendment was extended to processed fruits and vegetables by action of the House accepted by the Senate conferees. ${ }^{55}$ In decontrolling fresh fruits and vegetables, Congress had exempted from price ceilings items accounting for approximately 10 percent of the food dollar. Processed fruits and vegetables (canned, frozen, etc.) accounted for another 11 percent.

Moreover, although arguments could be made as to the difficulties of controlling the prices of fresh fruits and vegetables, regulation of the canning industry and of the distributive levels beyond the canning industry was relatively easy. The regulations applicable to canned and frozen fruits and vegetables were generally workable and fair. What the canning industry actually sought, and what it could prob-

53. The Harrison Amendment provides that "No ceiling shall be established or maintained under this title for fruits or vegetables in fresh or processed form." It was added to $\$ 402$ (d) (3) of the Defense Production Act by $\$ 106(\mathrm{~b})$ of the Defense Production Act Amendments of 1952, 66 STAт. 298 (1952).

54. 98 Cong. Rec. 6672-4 (June 4, 1952); H.R. 8210, 82d Cong., 2d Sess. $\S 104(b)(1952)$.

55. 98 Cong. Rec. 7867-72 (June 20, 1952). 
ably have expected, was suspension in those areas where supplies had been so great as to bring prices down substantially below the ceiling.

Farmers get only about 20 percent of the retail prices of canned fruits and vegetables. Hence the major effect of the Harrison Amendment as applied to canned items was to decontrol the 80 percent of the retail price accounted for by canners' and retailers' margins. This fact, as well as the unfortunate consequences of decontrol of such important cost of living items if there were ever a return of acute inflationary pressure, should have been enough to defeat the amendment.

A brief word on the manner in which the legislation was adopted is again in order. That part of the Harrison Amendment which exempted fruits and vegetables in processed form, was never presented to either of the Banking and Currency Committees. There was of course no committee action on the suggestion and the debate on the House floor was in generalities. Once again Congress acted without the benefits of the consideration and advice of its own committees.

The Bricker and Rains Amendments.-Further steps to whittle away controls were taken in the Bricker and Rains Amendments.

The Bricker Amendment provides as follows:

"(1) No rule, regulation, order, or amendment thereto issued under this title shall fix a ceiling on the price paid or received on the sale or delivery of any material in any State below the minimum sales price of such material fixed by the State law (other than any so-called 'fair trade law') now in effect, or by regulation issued pursuant to such law." ${ }_{66}$

OPS was thus required to adjust its ceilings to conform to state minimum price laws. In some situations OPS had done so as a matter of discretion. But it is another thing entirely to require OPS to defer to state minimums as a matter of law. The urgent need to control inflation obviously should be the overriding consideration in any determination as to whether federal or state policy should be decisive in determining prices.

The Rains Amendment ${ }^{57}$ forbids the establishment of ceilings below the state minimum price for milk; and if the state fixes a maximum price for milk, the ceiling must be equal to the maximum. State minimum milk price regulation is designed primarily to protect pro-

56. The amendment was added by section 111 of the Defense Production Act Amendments of 1952, 66 Stat. 300 (1952). See SEN. Rep. No. 1599, 82d Cong., 2d Sess. 26-7 (1952); H.R. REP. No. 2177, 82d Cong., 2d Sess. 26 (1952); H.R. REp. No. 2352, 82d Cong., 2d Sess. 20 (1952).

57. The amendment was added to $\$ 402$ (d) (3) of the Defense Production Act by $\$ 106(\mathrm{~b})$ of the Defense Production Act Amendments of 1952, 66 STAT. 298 (1952). See H.R. Rep. No. 2177, 82d Cong., 2d Sess. 23 (1952). 
ducers and as a result state boards dealing with milk have not been primarily consumer-minded. This is not a criticism but a fact. The likelihood is that consumers will not fare as well under state minimum milk price regulation as they would under price ceilings established by an agency whose primary responsibility is to protect consumers. On the other hand there could be no serious argument that either the Bricker or the Rains Amendment was necessary to protect sellers, since the Defense Production Act, itself, contains adequate safeguards to this effect.

The Wolcott Amendment.-Finally, the difficulty experienced by Congress in dealing with a technical subject is illustrated by the Wolcott Amendment modifying the review provisions of the Emergency Court of Appeals. ${ }^{58}$ This court, created pursuant to the Defense Production Act, has been assigned exclusive jurisdiction to determine the validity of price control regulations.

Section 408(b) of the Act formerly provided in part that:

"No such regulation or order shall be enjoined or set aside, in whole or in part, unless the complainant establishes to the satisfaction of the court that the regulation or order is not in accordance with law, or is arbitrary or capricious."

The Wolcott Amendment, as introduced in the House, deleted this provision and substituted a preponderance of evidence rule as the standard for judicial review. This amendment never was considered by either of the Committees. It was offered on the floor by Mr. Wolcott, senior Republican on the House Committee, and accepted by Mr. Spence, Chairman of the Committee, as merely subjecting the Office of Price Stabilization to the same standard of judicial review as other administrative agencies. ${ }^{69}$

It is obvious that both Mr. Wolcott and Mr. Spence were under a misapprehension on this score. "Substantial evidence," rather than a preponderance of the evidence, has been the conventional test of judicial review, and that test is now embodied in section $10(\mathrm{e})$ of the Administrative Procedure Act. ${ }^{60}$ Nevertheless, with the agreement of these two leading members of the House Banking and Currency Committee, the amendment went through on a voice vote.

The amendment was actually a complete rewrite of the provisions defining the jurisdiction of the Emergency Court. The Court was for

58. The Wolcott Amendment is a complete rewrite of the former provisions of section 408 of the Defense Production Act relating to court review, 64 STat. 808, (1950) 50 U.S.C. App. \& 2108 (Supp. 1952). The amendment was added by section 113 (b) of the Defense Production Act Amendments of 1952, 66 STAт. 302 (1952).

59. 98 Cong. Rec. 7865-6 (June 20, 1952).

60. 60 STAT. 243,5 U.S.C. $\$ 1009$ (e) (1946). 
the first time granted power to enjoin temporarily enforcement of a price regulation. Moreover, the automatic stay of the court's decisions pending determination by the Supreme Court was deleted. These changes made by the Wolcott Amendment were not even referred to in the debates, and it is doubtful that any member who voted for the bill was aware of the changes or their significance.

The conferees modified the Wolcott Amendment by substituting for the preponderance of evidence rule the Administrative Procedure Act test of substantial evidence. ${ }^{61}$ However, the other changes made by the Wolcott Amendment were retained. Fortunately, the subsequent legislative history indicates that Congress intended the Emergency Court of Appeals to use its injunction power sparingly; ${ }^{62}$ and in its first and only decision under the new statute, the court has indicated clearly that it will comply with this intent. ${ }^{63}$

The lesson to be drawn from the enactment of the Wolcott Amendment is the manner in which legislative changes of an important but technical character can slide through on the floor without proper consideration. The merits of the changes made by the Wolcott Amendment obviously warranted considerably more study than the members of Congress either on the House floor or in the Conference Committee were able to give it.

The Danger of Creeping Inflation.-The law as passed by Congress was as good as could be expected in the political and economic climate existing in the summer of 1952. The very fact of its extension gives consumers a feeling that there is some protection against soaring prices. This psychological safeguard may prevent some scare buying which would in itself build up inflationary pressures. But the cumulative effect of the many amendments was such that the law, as extended, afforded only limited protection against inflationary price increases. It was a law designed to make price control painless to the farmer, to the manufacturer, and to the retailer. Indeed, large numbers of sellers were exempted entirely from its provisions. It is better than no law and in some areas it can protect consumers, farmers, and the Government against price increases. Its anti-rollback provisions, its cost-plus provisions, and its markup provisions, while making price controls more palatable to sellers, spread dangerously thin the protection to consumers. During a period of inflation organized groups whose goods or services are in demand can pretty well take care of themselves. The

61. Section 408, as amended, 66 STAT. 302 (1952).

62. H.R. Rep. No. 2352, 82d Cong., 2d Sess. 24-5 (1952) ; 98 Cong. Rec. 8593 (June 28, 1952).

63. Wing v. Arnall, 198 F.2d 571 (Em. Ct. App. 1952). 
larger manufacturer, organized labor, and most farmers will be able to take care of themselves in a semi-inflationary economy. It is the unorganized white collar worker and the person living on fixed income who are the forgotten men of this law.

If this were a period of full-blown inflation, consumer outcries could be counted upon to produce a stronger law. But this is a garter snake kind of inflation-creeping and spotted. Creeping inflation is just as harmful and more insidious than full inflation. If prices increase at the rate of four percent a year, a retired worker on a fixed income is just as badly off at the end of two years as he would be at the end of one year if prices increased eight percent a year. The difference is that in the period of creeping inflation, Congress is reluctant to afford the full protection that is demanded when full inflation exists.

Because inflationary pressures are spotty, those charged with administering controls face another dilemma. There can be no question that in the consumer soft and durable goods area there is sufficient market softness so that widespread suspension of controls is likely. This in itself does not hurt the consumer because these items are not selling at ceiling prices anyway. The difficulty is, however, that with substantial areas not under price control, it may be a psychological and political impossibility to impose tight price control standards on those areas which remain under control. And so today those on fixed incomes or those workers, particularly white collar workers, whose bargaining position is relatively weak, face a slow decline in real income over a substantial period of time. A large part of the American middleclass, which has been the major source of political stability, is being ground between the millstones of relatively fixed incomes and slowly rising living costs. The existing price control law will afford some protection and will delay some price increases, but it is not strong enough to resist creeping inflation.

\section{Improvement of Congressional Review}

The problems presented by the 1952 extension of price control, however, go farther than merely a question of the extent to which a government should direct the economic life of the country in times of inflation. It presented also the problem of proper relationship of the legislature to the executive in administering price control, and the proper procedures to be followed within Congress itself in order to achieve intelligent legislation in a complex economic field like price control. 
The problem has been subject to continuous and active study, particularly in the last twenty years, not only by political scientists but also by thoughtful members of Congress and by Congressional committees. ${ }^{64}$ The 79th Congress appointed a Joint Committee on the Reorganization of Congress headed by Senator LaFollette, which conducted extensive hearings and made thirty-seven recommendations on changes in organization and procedure. The Legislative Reorganization Act of $1946^{65}$ enacted some but by no means all of these changes into law. It did improve the committee structure, committee procedures, and the technical facilities available to Congress. It failed to enact those recommendations which would have provided more responsible party government in Congress, closer liaison between the House and the Senate, and closer legislative-executive liaison.

Regular Committee Review.-It frequently has been proposed that committees subject the administrative agencies under their jurisdiction to frequent, periodic and systematic review. ${ }^{66}$ Hearings would be held at frequent and regular intervals. Administrators not only would report on their activities but also would discuss with the committee major policy matters involving both past and prospective problems. There would be a regular question period when the committee members could explore grievances caused by agency action and probe into administration operations. The hearings would be supplemented by day-by-day staff liaison between the committee and the agency staff and by full written reports by the agency to the committee. This proposal was made by the LaFollette Committee, ${ }^{67}$ but only partially adopted in the Legislative Reorganization Act of $1946 .{ }^{68}$ It is partictrlarly effective if supplemented by an agency office manned by a top agency official on Capitol Hill. ${ }^{69}$

On the whole, Congressional committees do not fully employ these useful tools. ${ }^{70}$ In many cases, hearings are held only when Congres-

64. Particularly Senators Kefauver and LaFollette. See Kefauver \& Levin, A Twentieth Century Congress (1947). (1946).

65. 60 Stat. 812 (1946). See Galloway, Congress at the Crossroads 340-346

66. See Kefauver and Levin, op. cit. supra note 64, at 147-148. See also the discussion of the Smith Committee in Perkins, American Government and Politics: Congressional Self-Improvement, 38 AM. POL. SCT. REv. 504-5 (1944).

67. Sen. Rep. No. 1011, 79th Cong., 2d Sess. 12-13 (1946).

68. Section 136 provides that the appropriate committee shall exercise "continuous watchfulness" over the activities of administrative agencies subject to their jurisdiction and shall study the agency reports. 60 STAT. 832 (1946).

69. KeFAuver AND Levin, op. cit. sipra note 64 at 149-150.

70. See Galloway, The Operation of the Legislative Reorganization Act of 1946, 45 Amr. Poz. Scr. Rev. 41 (1951). 
sional grievances against agency conduct have accumulated into substantial irritation, or when some major crisis has arisen. In crisis hearings, administrators armed for battle feel obliged to defend themselves at all cost from Congressional onslaught. Expert testimony is used to build a defensive wall of rationalization of all administrative actions. Mutual irritation prevents an objective presentation or an objective appraisal of agency acts. ${ }^{71}$

The key to effective Congressional review is in the more widespread adoption of regular review procedures. ${ }^{72}$ It is obvious that these procedures lead to a better-informed Congress and to better personal relations. There are other substantial advantages. First, the questioning of agency officials is an effective safety valve against a Congressional blow-up because it gets problems resolved that otherwise would irritate over an extended period of time. Not only do Congressmen get things off their chest but the agency learns what is bothering Congress and can take action before minor irritations balloon into major problems. Second, hearings are held in a businesslike way in a calm atmosphere, which contrasts with the heated atmosphere characteristic when hearings are held only on occasions when a crisis has aroused Congressional tempers. ${ }^{73}$ Third, much of the discussion can center on prospective rather than past policy. Not only will this mean that Congress is better informed on the reasons for agency action, but, to the extent that the committee shares in the responsibility of major policy decisions, it will be less prone to destructive or uninformed criticism. If, for example, the Committee had participated in the roll-

71. "In June 1945, speaking almost plaintively before the reorganization group, Mr. Bowles, said: 'All too frequently the only contact between agency heads and members of Congress occurs on critical issues which must be dealt with. As a result, the top men in the executive branches of the Government often dread their contact with the legislators. Instead of a free-working relationship of intelligent people, all seeking the same general end, the contacts often are held in an atmosphere of suspicion, charges and misunderstanding." KEFAUVER \& LEVIN, op. cit. supra note 64 , at 148 .

72. "Informal conferences at the committee and/or staff level with agency officials is another method which has proved helpful in performing the oversight function. First used by Chairman Lanham and Administrator Blanford on national Housing matters, this method had helped resolve complaints and misunderstandings, made for closer cooperation, and laid a foundation of mutual respect and confidence. During the second session of the 80th Congress, the House Committee on Interstate and Foreign Commerce held a series of such meetings with representatives of 14 regulatory agencies in its field. The committee stated that these meetings enabled it to exercise closer supervision over these agencies; that they were a means of acquainting the new members of the committee with the activities with which they would become concerned; and that they provided a channel for the various agencies to present their ideas to the committee concerning possible measures for improving their work or making it more effective." Galloway, supra note 70, at 61 .

73. "Discussions relate not so much to policy or program as to administrative details which excite suspicion, irritation, and strain on both sides. Conferences at times when legislators were not after specific things which their constituents want would result in common ground, common purpose, and mutual respect." " APPLEBY, Big Democracy 159 (1945). 
back decisions of OPS, it might have had a fuller appreciation of their necessity. Fourth, administrative expertness will tend to be accompanied by administrative candor in discussing policies and in presenting factual considerations. Congressional committees will thus have at their disposal the technical expertness and experience accumulated from operations that can be found only in the executive. Finally, the committee will be better prepared to present the case against crippling amendments offered in floor debate by legislators who are not committee members.

Generally the Banking and Currency Committees plus the Joint Committee on Defense Production have employed some but not all of these techniques. The Committees worked diligently, received frequent reports from responsible agencies, and explored the vital issues before the agencies. On the other hand, the Committees conceived their functions as one of critical review of actions already taken. There was no regular reporting by agency officials on prospective as well as past policy. Many hearings, such as those conducted on the beef rollback and on the steel strike, were held in a crisis atmosphere. While the Committees had a responsibility to hear criticisms of the agencies, a disproportionate amount of their time was spent in hearing repetitious and lengthy criticism from industry witnesses. This course of action was particularly unfortunate because the scarcest commodity on Capitol Hill is time. The Committees had so many other responsibilities that they did not have time to explore fully many of the issues on which they acted.

Nevertheless it can be said generally that if Congress had relied on its Committees more heavily, there would be a better price control law today. The only major amendments recommended by the Committees were the Fugate and Bricker Amendments and the anti-rollback provision of the Capehart Amendment The third sentence of the Capehart Amendment was drafted by the Conference but both Committees in the fall of 1951 reported out new legislation repealing or substantially modifying it. The Herlong, Harrison, Wolcott and Butler-Hope amendments were floor amendments.

Improvement of Staff Facilities.-The effectiveness of the review depends upon the quality of the staff and the committee procedures. In turn the effectiveness of the staff depends upon attaining the personal confidence of the Committee, and particularly the Committee chairman. Certainly Congress needs more of a staff than it now has. Pursuant to the recommendations of the LaFollette Committee, Congress in passing the Legislative Reorganization Act of 1946 took a long step forward in providing an adequate staff to do the job. Moreover, many 
of the staffs, such as those of the Committees concerned with price control, are of high quality. Yet, Congressional staffs are spread far too thin to give Congress the kind of technical advice it really needs. While more staff is needed, the building of a large staff of experts in the Congress is certainly not the sole answer to the problem. The legislature could not hope to match the expertness of the agency because it would have neither as large a staff nor the invaluable background of operating experience. The effort should be to develop a staff of sufficient size and competence to understand the major technical problems and to help the committee in its deliberations on them. To go further is not only needlessly expensive but "the inevitable conflicts among experts will sharpen the diffierences between administrative and legislative branches, raising their disagreements to a higher plane by reinforcing their predilections with statistics." 74

Improvement of Committce Procedures.-The effectiveness of committee procedures depends upon the personality of the chairman, the composition of the committee and the competence of the staff. There is much that the staff, backed by the committee chairman, can do to make hearings more pointed and effective. ${ }^{75}$ By briefing of the committee on the issues in executive session in advance of hearing, by the grouping of witnesses so their testimony is focused on certain issues, by the briefing of witnesses' statements in advance of hearing for use of the committee members, and by preparing questions for use of members, the staff can make the hearings more meaningful. With the support of the chairman, the staff can cut down materially on the number of witnesses and avoid repetitious testimony. Moreover, the committee consideration of legislation in executive session can be helped by prepared summaries of issues and testimony. All of these techniques were employed in some degree by the committee staff working on price control. That they were not more fully employed was due not to lack of staff understanding of their effectiveness, but to the fact that committee members were so busy that briefing time was limited and the staff too small to handle all the problems presented.

Provisional Regulations. - It also has been proposed that Congressional review would be strengthened if the regulations of the agency were made provisional while filed with an appropriate committee. If the committee did not disapprove of the regulations within

74. Perkins, American Govermnent and Politics, 38 AM. PoL. Scr. Rev. 500, 508 (1944).

75. For a discussion of methods of improving committee procedures, see GalwowAY, op. cit. supra note 65 , at 182-184. 
a stipulated time, of ten or fifteen days, they would become effective. ${ }^{76}$ There can be no question that this proposal would strengthen the supervision of Congress; as an attempt to obtain an advance joint responsibility for policy action, it has considerable merit. While the British have had some success with the provisional order system, Parliament, as a whole, not just a committee, must disapprove and irresponsible action is prevented by a party discipline which is not present in Congress.

If only regulations involving major policy were submitted, the proposal might succeed. However, no practical distinction could be drawn between important regulations requiring Congressional approval, and unimportant ones which would go into effect immediately. A Congressman would consider any regulation important that affected a vocal constituent. For this reason, the cure is worse than the disease. Congressmen would be bogged down with decisions on hundreds of regulations and harassed by pressure from affected groups to intervene. The OPS, in a year and a half, issued 153 major regulations and 864 amendments or supplements, some of which also involved important policy matters and most of which vitally affected some industry which would be interested in Congressional intervention. Important Congressional work would be impaired and the activities of administrative agencies would be bogged down by endless Congressional controversy. A widespread use of the legislative veto would stop urgently needed action by the agency and prevent the development of any affirmative agency program. Congressional review would be directed toward countless small matters to the neglect of large policy matters.

Improvement of Floor Procedure.-Most of the improvement in floor procedure is not a matter of mechanics but a matter of improvement of party responsibility in Congress. ${ }^{77}$ There is, however, one

76. See KeFaUVER \& IEVIN, op. cit. supra note 64, at 151; LANDIS, THE ADministrative Process 77-80 (1938); Hyneman, op. cit. supra note 13 , at 166174; Young, This Is Congress 209-215 (1946).

77. Perhaps the oldest and most persistent suggestion to improve floor procedure is that Congress institute a regular question period of administrative officials on the floor of Congress similar to that successfully employed by the British Parliament. In England, this has served not only to inform the Parliament and improve the executive agencies by keeping the Minister on his toes, but has been an effective safety valve for letting off Parliamentary irritation. There has been strong opposition to the use of the question period in Congress. The opponents argue that it would be an impairment of the doctrine of separation of powers and that in the absence of the British Parliamentary system, with strong party discipline and a ministry composed of members of and responsible to Parliament, it would lead to most partisan and irresponsible discussion. While this suggestion is not likely to be adopted in the near future, it is likely that question periods will be used more extensively in the committees, rather than on the floor of Congress. See FINLETTER, CAN REPRESENTA- 
device that could be employed. In some instances Congress has recognized the danger of amendments to bills with a broad economic impact and of a technical nature where seemingly innocuous amendments can destroy the purposes of the bill. Thus, tax legislation is generally considered in the House of Representatives under a closed rule permitting introduction of amendments only by members of the committee with consent of the majority of the committee. No such rule and no such agreement prevailed in the consideration of the price control measure. Gag rule which takes authority away from the Congress as a whole and inhibits full discussion on the floor certainly has to be justified by extreme necessity. Moreover, since the Rules Committee determines whether a closed rule will be employed, it may be in a position to control the substance of the legislation introduced. If, however, the rules function were performed by a party policy committee, the closed rule could be employed in limited instances to strengthen party responsibility and to protect legislation from technical amendments on the floor. ${ }^{78}$

Legislative-Executive Cooperation Backed by Party Responsibility.-More significant than any improvement in mechanics are the underlying questions of the proper relationship between the executive and the legislature and the related problem of the role of the party in American politics. ${ }^{79}$ It is not suggested that the executive should set the policy and the Congressional leaders blindly follow it. The policy must be set by joint council of the Congressional and administration leaders and then supported by both. ${ }^{80}$ No such council would be of any great effectiveness unless it were backed by party responsibility

tTVe Government Do the Job? 87-8 (1945) ; Kefauver and Levin, op. cit. supra note 64 , at 70 ; Galloway, op. cit. supra note 65 , at $215-219$. But see Truman, op. cit. supra note 18 , at 530-531.

78. The British Parliament uses procedures which insure that technical amendments are sound and will not interfere with the objectives of the Act. The bill is passed by the House in principle only and on the second reading is referred to the standing committee. This committee has the obligation to perfect the bill technically, but it must act within the principle of the bill. The committee does not hear witnesses, but obtains the technical information from the responsible minister and the civil service. Thus the technical features of the bill are based upon the professional and technical expertness of the responsible civil servants, and cannot conflict with the objectives of the bill itself. See Finer, The British System, 18 U. of CHI. L. REv. 521 (1951).

79. The problem has occupied political scientists for a generation. Literally hundreds of proposals have been made cumulating in the four-year study and report of the Committee on Political Parties of the American Political Science Association, Towards a More Responsible Two Party System, 44 AM. PoL Scr. Rev., Supp. (1950). See also testimony of Mr. Bertram M. Gross, representing the Association. Hearings before the Committee on Expenditures in the Executive Department on Evaluation of the Effects of Laws enacted to Reorganize the Legislative Branch, 82d Cong., 1st Sess. (1951) p. 271.

80. See Finletrer, op. cit. supra note 77 , at 155-158, and Hyneman, op. cit. supra note 13 , at $571-572$. 
within the Congress itself. It is for these reasons that the effective use of majority policy committees in both houses is important. There are committees today that have similar titles, but they are not effective. $^{81}$ The important thing is how much attention is paid to their decisions.

There can be no question of the theoretical advantages of a joint executive-legislative council backed by party responsibility. When the legislators of the party in power and the executive are working together, the legislature participates in the formulation of policy and the technical resources of the executive are available to keep him informed on the more detailed side. When legislative leaders participate in the making of policy decisions, they accept the responsibility for obtaining Congressional support. This means that policies once agreed upon, have a greater chance of legislative acceptance. ${ }^{82}$ As party responsibility increases, government is made more effective. ${ }^{83}$ Legislation will

81. These committees have not been successful in establishing party discipline. Dr. Galloway has summarized their effectiveness as follows: "As devices for coordinating legislative policy-making and strengthening party leadership, the Senate policy committees have thus far failed to achieve their full potential. As instruments for promoting more effective liaison and cooperation with the President, they have also been a disappointment, partly because of the lack of similar party policy committees in the House of Representatives. Their limited achievements to date can be attributed, I suggest, to their composition, to the fragmentation of power in Congress and to the deep internal divisions within both of our major political parties." Galloway, supra note 70, at 51-52.

82. "These recommendations were based on the theory that in a democracy national problems must be handled on a national basis. Only through the expression of the will of the people by their support of political parties on the basis of their platform pledges can the majority will be determined. . . .

"Your committee recognizes the need for freedom of action on the part of the individual Member of Congress and his right to vote at any time against the announced policy of his party. But we feel that if party accountability for policies and pledges is to be achieved, stronger and more formal mechanisms are necessary. ...

"Improved understanding of each other's problems will be promoted by consultation before legislation is introduced to carry out pledged party promises and on matters of high administration policy. By giving congressional leaders a part in the formulation of policy, instead of calling upon them to enact programs prepared without their participation, better cooperation can be obtained. . . " SEN. REP. No. 1011, 79th Cong., 2d Sess. 12-13 (1946).

83. The English system demonstrates that criticism is not destroyed when the executive and the legislative work together in dealing with complex problems. There, of course, the ministers are the leaders of the party in Parliament itself. The result is that a government bill is not only supported by the executive and the legislative, but it is drafted and presented by them. The Government has at its disposal, as does the Parliament, all the resources of the civil service. They have available to them all the knowledge and experience and insight into the problems that have been accumulated through the years of dealing in them. Yet despite this integration of the executive and the legislative no one who reads proceedings of Parliament can believe that it is less alert of the dangers of arbitrary and unfair administrative action than is the Congress of the United States. Indeed, through the device of daily question periods, debates on matters of definite and urgent public importance, and debates on motions for adjournment. Parliament is not only alertly critical, but is able to quickly and effectively question deficiencies in administrative action and take corrective action. Finer, supra note 78 , at 521 . 
more often be based upon the national interests as conceived by the joint legislative-executive council and less often upon the demands of minority interest groups. While national pressure groups representing farmers, labor and business interests may influence national policy, their influence would be limited to major policy matters which would be the subject of full debate. Party responsibility will help prevent emasculation of legislation by floor amendments. It will tend to concentrate debate on major differences in policy between the parties. Democracy would not only be more competent, but more responsive.

In the long run, the ability of a responsible democratic legislature to deal with complex problems, to delegate authority, and to control and review that delegation, depends more on the resolution of these two basic problems than on any question of procedures within the executive or within the legislature. It is well to recognize, however, that complete legislative-executive cooperation and complete party discipline are neither necessary nor desirable in this country. The dominant fact in American politics is that this is a big country with many divergent local interests. It is not homogeneous like England. As long as the President is elected as predominantly a national representative and legislators as predominantly local representatives, there is bound to be conflict. Nor can there be party discipline based upon a strict national policy. National policy must be reconciled with local interests. Each region must be convinced that the over-all national policy is fair to it. Congressmen representing local interests cannot be expected to ignore those interests when they conflict with party policy based more on national considerations.

Even if the difficulties are recognized, there is much that can be done to improve both executive-legislative relationships and party responsibility. The existence of a joint council and party policy committee will establish a machine to iron out differences and to forge a national policy which will be reconciled as far as possible with local interests. Not only would compromise decisions be more acceptable to divergent interests, but the majority policy committee could be backed by many recognized techniques of party control. The greater use of party caucuses, the control of patronage and committee assignments, the assignment to the committee of the steering functions now held by the Rules Committee, and the financing of Congressional campaigns by the party, ${ }^{84}$ would all increase the influence of the joint council and the majority policy committee.

Existing political procedures are strongly entrenched, not only in the habits of Congressmen and administrators, but in the political fabric

84. See note 18 supra. 
of the country as a whole. There will be no quick change or rapid improvement. But the history of Congressional procedures since 1945 is a clear indication that a slow but sure improvement is under way and that small changes and new techniques add up to an impressive total of improvement. It is well for democracy that it does. It is not only good government that depends on a solution to this problem. The ability of Congress to deal with highly complex problems is in a large sense the measure of the ability of the nation to deal with them. And, to the degree that Congress is successful, democracy is successful in showing that a policy forged by the democratic process can meet the technical necessities of a complex age. 